\title{
Supervisory Role Of Regional Assembly (Mpd) On Notary Monitoring In Leaving The Area Without Legal Reasoning Which More Than 7 (Seven) Working Days In Banjarnegara
}

\begin{abstract}
Alfian Ridho Chusosi ${ }^{1}$, Carlito Da Costa $^{2}$ and Munsyarif Abdul Chalim ${ }^{3}$
Abstract. In the Constitution of the State in 1945 expressly stated that the Republic of Indonesia is legal state, is thus one of the most important tasks for the government is provide and ensure a sense of legal certainty for the citizens of the community members. In certain fields this task by the government through the Law given and entrusted to the Notary and vice versa community must also believe that the Agreement made that provides legal certainty for citizens, in accordance with the wording of Article 15 paragraph 1 of Act No. 30 of 2004 jo Act No. 2 of 2014 concerning Notary. The legal certainty in addition to the authenticity of a certificate that has the strength of evidence, ie outwardly, formal and material as well as the ethics of a Public Notary in the running position. In carrying out the duties of office of the Notary not only carry out the work mandated by legislation alone as well as running a social function that is very important is to be responsible for carrying out the trust placed in the general population it serves, Notary authorized to make the authentic act on all agreements, agreements and statutes required by the rules and regulations and / or desired by the stakeholders to be stated in an authentic agreement, agreement of guarantee certainty of the date of manufacture, save agreement, giving grosse, copy, and official copies.
\end{abstract}

Keywords: Public Notary, Regional Assembly, Legal Reasoning

\section{Introduction}

In the Constitution of the State in 1945 expressly stated that the Republic of Indonesia is legal state, is thus one of the most important tasks for the government is provide and ensure a sense of legal certainty for the citizens of the community members. In certain fields this task by the government through the Law given and entrusted to the Notary and vice versa community must also believe that the Agreement made that provides legal certainty for citizens, in accordance with the wording of Article 15 paragraph 1 of Act No. 39=0 of 2004 jo Act No. 2 of 2014 concerning Notary. In Indonesian dictionary, it can be seen that the term Notary means is a person authorized by the government (in this case the Ministry of Justice and Human Rights) to certify letters of agreement, wills, agreements etc.

Notary Code of Ethics for the profession is necessary to maintain the quality of legal services to the public because of this, the Indonesian Notary Association (INA) as the only organization recognized the truth according to the Notary Act \# 30 of 2004 in conjunction with Act of Notary No. 2 2014, establishes the Code for its members.

\footnotetext{
${ }^{1}$ Student of Master Program (S2) of Notaries Faculty of Law Universitas Islam Sultan Agung email alfianridho22@gmail.com

2 Students of Master of Law, Faculty of Law, Universitas Islam Sultan Agung email carlitodacosta030@gmail.com

${ }^{3}$ Lecture of Faculty of Law UNISSULA
} 
According to Munir Fuady position of a code of conduct for notaries is important, first, not only because the notary is a profession that needs to be governed by a code of ethics, but also because of the nature and essence of the work of notaries who strongly oriented towards legalization, so that it can be fundamental to the main law on status of property, rights and obligations of the clients who use the services of a notary. Second, to prevent injustice as a result of granting the status of property, rights and obligations that are not in accordance with the rules and principles of law and justice, so as to disrupt public order and also interferes with individual rights of people seeking justice, then the world indispensable notary also a good professional ethics and modern. ${ }^{4}$

In line with the terms of the code of ethics as an ethical standard can be explained as follows:

- Ethical standards and assign responsibility to explain to the client, the institution (institution), and society in general.

- Ethical standards for the profession expert help in determining what they should do when they face ethical dilemmas in their work.

- Ethical standards for the profession letting maintain the reputation or the name and function of the profession in society against the evil behavior-behavior of certain members.

- The ethical standards reflects the moral expectations of the community. Thus, the ethical standards of the profession ensures that pars members will abide by the code of professional conduct in his ministry.

- Ethical standards is fundamental to maintaining behavior and integrity or honesty of the experts of the profession. ${ }^{5}$

Based on the above, the subject matter can be formulated as follows: What is Supervisory Role Of Regional Assembly (MPD) On Notary Monitoring In Leaving The Area Without Legal Reasoning Which More Than 7 (Seven) Working Days In Banjarnegara; What barriers and solutions role of the Regional Supervisory Council (MPD) in monitoring the performance of the Notary in Law Notary.

\section{Research Methods}

This research used social legal research approach, Tamahana stated that socio-legal studies are addressed to Law and Society Studies ${ }^{6}$ According to F.X. Adji Samekto, Social legal studies conceptualize law as the norm and simultaneously as reality. The reviewer in socio-legal studies demands the mastery of the doctrines of law which have been established within the jurisprudence itself (as a priori and not free of sciences), and the examination of the theories of the operation of the law, as a consequence which sees law as reality. ${ }^{7}$ In the analysis of normative legal research is not the data, but through legal materials as mentioned above. Thus, relation between analytical methods approach the problem. Analysis the law which collected in this study will be conducted by description, interpretation, evaluation, argument and systematization.

\footnotetext{
${ }^{4}$ Munir Fuady 2005 Profesi Mulia (Etika Profesi Hukum bagi Hakim Jaksa Advokat Notaris Kurator dan Pengurus Bandung: PT. Citra Aditya Bakti p.133.

5 Suhrawardi K. Lubis op.cit. p 13. See also Spillane in Lilian Tedjosaputro p 52.

${ }^{6}$ Anis Mashdurohatun, Redyanto Sidji, Gunarto and Mahmutarom, Factors Causing Banking Cyber Crime in Indonesian, International Journal of Economic Research, Volume 14 Number 15 2017, p.295

7 Ibid.
} 


\section{Result And Discussion}

\subsection{Supervisory Role Of Regional Assembly (MPD) On Notary Monitoring In Leaving The Area Without Legal Reasoning Which More Than 7 (Seven) Working Days In Banjarnegara}

It can take an example of the role of MPD imposed sanctions against the notary who violate the rules of the post of notary particularly in Banjarnegara. Supervision of the Notary is very important to people's lives, especially the Notary itself. Notary increasing amount each year, resulting in increasing competition in the Notary to be professional and improve their quality. Prior to the enactment of Act No. 2 of 2014 concerning Notary legal protection against Notary regulated in Act of Notary No. 30 of 2004 stipulates that for the judicial process, the investigator, prosecutor, or judge with the approval of the Assembly Regional Supervising Notary authorized to minutes Agreement and take photocopies or letters attached to the minutes of the Notary agreement or protocol with the approval of the Regional Supervisory Council of Notaries.

Regional Supervisory Council of Notaries in Banjarnegara forward, can also be done by developing a progressive legal thought, which in essence: assert that the law is true for man, not man for the law otherwise. ${ }^{8}$

Ground of the Supervisory Council stipulated in Act No. 2 of 2014 on UUJN and UUJNP. Some examples of violations of the Law Notary conducted by unscrupulous Notary especially happens in general, particularly in the notary-public notary in the work area Banjarnegara is in the manufacture of the agreement of Notary and one of several notaries who deliberately leave the work area without a legitimate reason in excess of seven (7) working days,

While the offense is very attention Supervisory Council of Regency Banjarnegara is against one notary in Banjarnegara notary who often do not depart or enter consecutive working in more than seven (7) days notabened quite senior in Banjarnegara. Close supervision of the Assembly Regional Supervisor Banjarnegara would result from measures taken by that is, delivery or warnings / sanctions orally has not changed the habits of the notary, which in turn alerts written enough to make the notary became alarmed even faith do not want to repeat his actions in working as a notary officials.

Can be added as a reference for future monitoring in addition to supervising the performance of the notary on monitoring even checking in the manufacture of the agreement in Banjarnegara has been rampant, namely: ${ }^{9}$

- Agreement made without the presence of witnesses, but in agreement itself was called and declared "in the presence of witnesses".

- The agreement in question was not read by the Notary.

\footnotetext{
${ }^{8}$ Let Rahardjo Satjipto 2007 Biarkan Hukum Mengalir Catatan Kritis tentang Pergulatan Manusia dan hukum Jakarta Pg. 20.

9 Jurnal.pdii.go.id Wiratni Ahmadi Kode Etik Notaris pp 3120 September 2011
} 
- The agreement in question is not signed before the Notary, the agreement minutes even carried by others and signed by and in a place that is not known by the Notary concerned.

Confirmed also by Satjipto, that rule of law must be read in progressive, not just glued to implement "verses" formalistic legal regardless sociological context. Even is a necessity for the whole field of legal science to look at the context of the association with other sciences, such as sociology, anthropology, economics, psychology and so on. ${ }^{10}$

\subsection{Obstacles and Solutions Role of the Regional Supervisory Council (MPD) Banjarnegara in performance monitoring Notaries in the Act of Notary.}

Barriers that occur particularly in the area Banjarnegara would become a classic story that occurred in the Supervisory Council of Regions in general that occurred in Indonesia, namely: In practice, duties and functions that may certainly meet resistance was trivial from a variety of factors, namely:

- Non Preferably,

- The lack of response, attention or sensitivity of the Supervisory Council of the District of Banjarnegara,

- The notary who is actually a colleague of Banjarnegara Regional Supervising Council,

- And intimidation of those who notabened Notary is a former "thugs". ${ }^{11}$

Assembly Solutions Regional Supervising Banjarnegara, namely: According to the author, and speaker, implementation or very significant Authority is of the Regional Supervisory Council must be implemented carefully and regular agenda. For example, with the implementation of the fingerprint at the notary office work connected online or thrifty with the inspection system of attendance / presence of a Public Notary presence than that. $^{12}$

The role that the Regional Supervisory Council of Notaries in the implementation of the code of ethics Notary by Act No. 30 of 2004 in conjunction with Act No. 2 of 2014 On Notary, there are at least three (3) main thing, namely:

- Doing Oversight

- Conduct training

- Examination.

That the supervision of the implementation of the Notary, while this is done by MPD Notary synergy with other law enforcement authorities, as well as informal coordination with the institutional organization Notary

\section{Closing}

Based on the description that was raised, it can be concluded the following; Research results from the conclusion, the authors suggest:

\subsection{Conclusion}

- Supervisory Council of the District of Banjarnegara.

10 Satjipto Rahardjo 1996 Ilmu Hukum Citra Aditya Bakti Bandung Pg 18.

${ }_{11}$ Results of interviews with informants dated March 152018 the MPD Banjarnegara

12 Results of interviews with informants dated March 162018 the MPD Banjarnegara 
Regional Supervisory Council of Notaries Banjarnegara forward, can also be done by developing a progressive legal thought, which in essence:

- Insists that the law is true for man, not man for the law otherwise.

- Ground of the Supervisory Council stipulated in Act No. 2 of 2014 on UUJN and UUJNP.

- Some examples of violations of the Law Notary conducted by unscrupulous Notary especially happens in general, particularly in the notary-public notary in the work area Banjarnegara is in the manufacture of the agreement of Notary and one of several notaries who deliberately leave the work area without a legitimate reason in excess of seven (7) working days,

While the offense is very attention Supervisory Council of Regency Banjarnegara is against one notary in Banjarnegara notary who often do not depart or enter consecutive working in more than seven (7) days notabened quite senior in Banjarnegara. Close supervision of the Assembly Regional Supervisor Banjarnegara would result from measures taken by that is, delivery or warnings / sanctions orally has not changed the habits of the notary, which in turn alerts written enough to make the notary became alarmed even faith do not want to repeat his actions in working as a notary officials.

- Barriers that occur particularly in the area Banjarnegara would become a classic story that occurred in the Supervisory Council of Regions in general that occurred in Indonesia, namely:

In practice, duties and functions that may certainly meet resistance was trivial from a variety of factors, namely:

- Non Preferably,

- The lack of response, attention or sensitivity of the Supervisory Council of the District of Banjarnegara,

- The notary who is actually a colleague of Banjarnegara Regional Supervising Council,

- and intimidation of those who notabened Notary is a former "thugs". ${ }^{13}$

\subsection{Suggestion}

- In order not to become an obstacle and the role of the Supervisory Council of Regions in general, particularly in the Banjarnegara namely;

- Needs to be improved by the Minister of Justice and Human Rights as a Notary Supervisory organization against members of the Regional Supervisory Council. To choose the members who sit on the MPD people who are independent and have an honest attitude and integrity, as well as coordinated and comprehensive evaluation of the performance of the Supervisory Council of notaries who are in the Central Region and the Region every year.

- The government should be doing repairing against Notary Supervisory Council particularly MPD. Where the government provides a special office of the MPD. Because not all agencies Notary Supervisory Regions has remained at the Regional Office.

${ }^{13}$ Results of interviews with informants dated March 152018 the MPD of Banjarnegara 
- Indonesian Notary Association need to provide guidance to the Notary on duty at the regional level, in the Center Region and enforce the Code of ethics Notary more Decisive And More structured against the duties and responsibilities of the Notary Notaries in Maintaining ethics.

- Implementation of the Authority is very significant or is of a Regional Supervisory Council must be implemented carefully and regular agenda. For example, with the implementation of the fingerprint at the notary office work connected online or thrifty with the inspection system of attendance / presence of a Public Notary presence than that.

- Suggestions to notaries who notabened mentioned in the discussion are:

- Carry out the work according to the rules and based on Pancasila

- Comply with the code of conduct notary.

- Fix themselves in carrying out the performance as a notary that brings roles and responsibilities in an agreement that the certificate does not become a agreement under hand.

\section{References}

[1] Anis Mashdurohatun, Redyanto Sidji, Gunarto and Mahmutarom, Factors Causing Banking Cyber Crime in Indonesian, International Journal of Economic Research, Volume 14 Number 152017

[2] Munir Fuady 2005 Profesi Mulia (Etika Profesi Hukum bagi Hakim Jaksa Advokat Notaris Kurator dan Pengurus Bandung PT. Citra Aditya Bakti.

[3] Rahardjo Satjipto 2007 Biarkan Hukum Mengalir Catatan Kritis tentang Pergulatan Manusia dan hukum Compass Publishers Jakarta.

[4] Satjipto Rahardjo 1996 IImu Hukum Citra Aditya Bakti Bandung.

[5] Suhrawardi K. Lubis 2006 Etika Profesi Hukum Jakarta Sinar Grafika

[6] Jurnal.pdii.go.id Wiratni Ahmadi Kode Etik Notaris 20 September 2011 